\title{
Determinants of Muslim Decisions in Buying Fast Food In Salatiga
}

\author{
Muhammad Khoirul Afnan ${ }^{1 *}$ and Saifudin ${ }^{2}$ \\ ${ }^{1}$ Sharia Economics Study Program, IAIN Salatiga, Indonesia \\ ${ }^{2}$ Sharia Business Management Study Program, IAIN Salatiga, Indonesia
}

\begin{abstract}
This study also aims to determine the effect of halal certification, halal awareness, and religiosity on purchasing decisions with purchase intention as an intervening variable. The population in this study were consumers of Geprek Sa'i Salatiga. A total of 97 respondents were selected as respondents using the purposive sampling technique. Methods of data analysis using regression test and path analysis test. The results show that buying interest affects purchasing decisions while halal certification, halal awareness and religiosity have no effect. Meanwhile, halal awareness affects buying interest, while halal certification and religiosity have no effect. As for halal certification, halal awareness and religiosity affect purchasing decisions through buying interest as an intervening variable.
\end{abstract}

\section{Introduction}

Today the number of Muslims is very large and spread all over the world. Indonesia is a country that has the largest number of Muslims from other countries in the world. Indonesia is a country with the largest Muslim population globally, even far above Arab countries such as Saudi Arabia, Iran, Iraq and others. Such a large population of Muslims in Indonesia is a potential market for food producers to enter. This will certainly be a phenomenon that marketers should consider in Indonesia to increase sales of their products (Syahputra \& Hamoraon, 2014).

Based on data sourced from the Institute for the Study of Food, Drugs and Cosmetics of the Indonesian Ulema Council (LPPOM-MUI) in 2012-2019 regarding certified products circulating in Indonesia, in 2016 there were 6,564 halal-certified companies, 7,392 halal certificate holders, and 114,264 products declared halal. In 2017 there were 7,198 halalcertified companies, 8,157 halal certificate holders, and 127,286 products declared halal. In 2018 there were 11,294 halal-certified companies, 17,398 halal certificate holders, and 204,222 products declared halal. In 2019, there were 13,951 halal-certified companies, 15,495 halal certificate holders and 274,796 halal products.

\footnotetext{
* Corresponding author: afnanirul11@gmail.com
} 


\section{$A I \overline{I E B}$ Annual International Conference \\ on Islamic Economics and Business, 2021}

Table 1. LPOM-MUI Data 2012-2019

\begin{tabular}{|c|c|c|c|}
\hline Year & $\begin{array}{c}\text { Number of } \\
\text { companies }\end{array}$ & $\begin{array}{c}\text { Number of } \\
\text { Halal } \\
\text { Certificates }\end{array}$ & $\begin{array}{c}\text { Number of } \\
\text { products }\end{array}$ \\
\hline 2012 & 5.829 & 6.157 & 32.890 \\
\hline 2013 & 6.666 & 7.014 & 64.121 \\
\hline 2014 & 10.180 & 10.322 & 68.572 \\
\hline 2015 & 7.940 & 8.676 & 77.256 \\
\hline 2016 & 6.564 & 7.392 & 114.264 \\
\hline 2017 & 7.198 & 8.157 & 127.286 \\
\hline 2018 & 11.249 & 17.398 & 204.222 \\
\hline 2019 & 13.951 & 15.495 & 274.796 \\
\hline
\end{tabular}

Source: LPPOM MUI (2020)

The development of the fast-food halal food business itself is growing rapidly, along with the increasing busyness of society. This is because the workers and the community have been busy with their activities and prefer something instant to fulfil their daily needs. In Salatiga, a halal fast food restaurant is quite well known with the brand "Ayam Geprek Sa'i," This business was established in early 2017 and had a sharia restaurant concept where good quality products and fast service are the main priority. In addition, convenience facilities and affordable prices are added values given to consumers (Harfania, 2018).

The selection of Geprek Sa'i Salatiga consumers as objects in this research is based on considerations where Geprek Sa'i itself is unique. The menus served are different from others, using Islamic names and sharia elements in presentation and management, halal. Currently, consumer awareness about halal products is also high. So that researchers want to know the level of buying interest when deciding to buy halal food.

\section{Literature Review}

\subsection{Theory of planned behaviour (TPB)}

TPB postulates three conceptually independent determinants of intention. The first is an attitude towards behaviour which refers to how a person has a favourable or unfavourable evaluation or assessment of the behaviour in question. Attitude towards behaviour is an overall evaluation of a person performing the behaviour in question (Ajzen, 2002). The second predictor is a social factor called subjective norm which refers to the perceived social pressure to perform or not perform the behaviour. The third antecedent is the level of perceived behavioural control, which refers to the perceived ease or difficulty of performing the behaviour and is assumed to reflect past experiences and anticipated barriers and obstacles (Ajzen, 1991).

In general, the more attitudes and subjective norms supported, the more control people have over their behaviour, and the more willing they are to implement the responses discussed. By asking respondents to rate each predictor variable based on a series of scales, all predictor variables in TPB can be directly evaluated. Instead, based on beliefs that are in line with attitudes towards behaviour, behavioural control and subjective norms, indirect analysis can be carried out (Ajzen, 2002).

\subsection{Buying decision}

The purchase decision gives the most preferred brand of the various alternatives, but two factors can be between the purchase intention and the purchase decision. The first factor is 


\section{$A I C \overline{I E B}$ Annual International Conference \\ on Islamic Economics and Business, 2021}

attitude, and the second factor is the situational factor (Armstrong et al., 2014). Making purchasing decisions consists of problem recognition, information search, evaluation of alternatives, purchase decisions, and post-purchase behaviour. Purchase decisions by consumers are related to the emotions and feelings of consumers, where someone will feel happy and satisfied in buying the product so that it will strengthen their interest in buying it. In purchasing decisions, Anggadwita et al. (2020) states that there are several indicators in purchasing decisions, namely need recognition, information search, evaluation of alternatives, purchase decisions, and post-purchase behaviour.

\subsection{Halal Certification}

Halal is defined as a document issued by an Islamic organization that certifies that its products meet Islamic guidelines as defined by the certification body (Riaz \& Chaudry, 2003). The objective of the MUI Halal Certification, according to LPPOM MUI (2020), is to provide certainty of halal status so that it can reassure consumers in consuming it. The producers guarantee the continuity of the halal production process by implementing the Halal Assurance System. For companies that want to obtain LPPOM MUI halal certificates, both processing industries (food, medicine, cosmetics), Slaughterhouses (RPH), and restaurants/catering/kitchens must register for halal certification and meet the requirements for halal certification.

Saifudin \& Puspita (2020) state halal certification indicators; namely, halal certification is important, choosing a halal certification, feeling security with halal certification, and understanding the difference between halal and non-halal.

\subsection{Halal Awareness}

Awareness is the ability to understand, feel, and become aware of events and objects. Halal awareness, according to Ahmad et al. (2013) known based on whether or not a Muslim understands what is halal, knows the correct slaughter process and prioritizes halal food for them to consume. Meanwhile, according to Nofianti \& Rofiqoh (2019), awareness is the level of understanding of Muslims in issues related to the concept of halal. Such understanding includes understanding the product and its elements. Muslim awareness is characterized by knowledge about the process of slaughtering, food packaging, and food hygiene following Islamic law. Halal awareness is the level of understanding of Muslims in knowing issues related to the halal concept. Yunus et al. (2014) mention several indicators of halal awareness, namely knowledge about halal, being aware of halal due to religious obligations, cleanliness and product safety, knowing the manufacturing process, and caring about food.

\subsection{Religiosity}

Religiosity is the overall function of the individual soul, including beliefs, feelings, and behaviours directed consciously and seriously to the teachings of his religion by working on five religious dimensions, including obligatory worship procedures (Stark \& Glock, 1968). Religiosity is a comprehensive unity of elements, which makes a person called a religious person, not just a religion. Religiosity affects one's purpose in life and the responsibility to God, oneself, and others. Consumer religiosity also depends on a person's commitment to his religion. For a Muslim, religiosity can be known from the extent of knowledge, belief, implementation and appreciation of the religion of Islam. Consumers who have a high level of religiosity will usually buy food that is clearly halal and always avoid activities that involve them consuming what haram is. 


\section{$A I C \overline{I E B}$ Annual International Conference \\ on Islamic Economics and Business, 2021}

According to El-Menouar (2014), there are several indicators in religiosity, namely belief, ritual, loyalty, experience, knowledge, and consequences.

\subsection{Buying Interest}

Interest is defined as a personal matter related to attitudes, where individuals interested in an object will have the urge to perform a series of behaviours to get the object. At the same time, the purchase has the meaning of a situation where someone decides to make a transaction based on previous experience (Nugraha, 2017). The interest in making a purchase creates a motivation that continues to be recorded in his mind and becomes a very strong activity. At the end, when a consumer has to fulfill his needs, he will actualize what is in his mind. Thus, buying interest will arise during the decision-making process.

There are four stages of producers determining buying interest or determining consumer encouragement in making purchases of the products or services offered (Kotler \& Lee, 2008), including Attention, Interest, Desire and Action. According to Kusumawati \& Saifudin (2020), There are several indicators of buying interest, including determination in purchasing, always looking for information in purchasing, not looking for other products, desire to make a purchase, referral effort in purchasing, and estimation of satisfaction that will be obtained with the purchase.

\section{Method}

The type of research used is quantitative. The population in this study were all Geprek Sa'i Salatiga consumers. The sample is determined using the Lemeshow formula to find the number of respondents because the total population is not known with certainty. By using this method, a sample of 97 respondents was obtained. The independent variables (independent) in this study are halal certification, halal awareness, and religiosity. The intervening variable in this study is buying interest, while the dependent variable (dependent) is purchasing decisions. The sampling technique used in this research is purposive sampling. Purposive sampling is a sampling technique based on certain considerations (Sugiyono, 2015).

To test the hypothesis being tested, data analysis was used through a partial test (t-test) and path analysis test. The t statistic test shows how far the influence of one explanatory or independent variable is individually in explaining the variation of the dependent variable. In contrast, the path analysis test is used to test the intervening variables (Ghozali, 2013). All data collected was processed using IBM SPSS 25.0 software for windows.

\section{Results and Discussion}

Statistical tests were conducted to determine how far the influence of the independent variables individually on the dependent variable being studied. The following are the test results using the SPSS version 25.0 program.

Tabel 4.1 T-Test Results (Equation 1 Against Y)

\begin{tabular}{|c|c|c|c|c|c|c|}
\hline \multicolumn{2}{|c|}{} & \multicolumn{6}{c|}{ Coefficients } & Sig. \\
\multicolumn{2}{|c|}{ Model } & \multicolumn{2}{|c|}{$\begin{array}{c}\text { Unstandardized } \\
\text { Coefficients }\end{array}$} & $\begin{array}{c}\text { Standardized } \\
\text { Coefficients }\end{array}$ & T & \\
\cline { 3 - 7 } \multicolumn{2}{|c|}{} & B & Std. Error & Beta & & .141 \\
\hline 1 & (Constant) & 7.108 & 4.790 & & .484 & .415 \\
\cline { 2 - 7 } & Total_X1 & .178 & .218 & .094 & .818 & \\
\hline
\end{tabular}




\begin{tabular}{|l|c|c|c|c|c|c|}
\hline & Total_X2 & -.354 & .224 & -.199 & -1.581 & .117 \\
\cline { 2 - 6 } & Total_X3 & .119 & .058 & .189 & 2.043 & .044 \\
\cline { 2 - 6 } & Total_Z & .980 & .139 & .674 & 7.064 & .000 \\
\hline \multicolumn{7}{|c|}{ a. Dependent Variable: Total_Y } \\
\hline
\end{tabular}

Source: Processed data, 2021

Tabel 4.2 T-Test Results (Equation 2 Against Z)

\begin{tabular}{|c|c|c|c|c|c|c|}
\hline \multicolumn{2}{|c|}{} & \multicolumn{2}{c|}{$\begin{array}{c}\text { Cnstandardized } \\
\text { Coefficients }\end{array}$} & $\begin{array}{c}\text { Standardized } \\
\text { Coefficients }\end{array}$ & T & Sig. \\
\cline { 3 - 7 } \multicolumn{2}{|c|}{} & Bodel & Std.Error & Beta & & \\
\hline \multirow{3}{*}{1} & B Constant) & 13.351 & 3.301 & & 4.045 & .000 \\
\cline { 2 - 7 } & Total_X1 & .109 & .163 & .083 & .669 & .505 \\
\cline { 2 - 7 } & Total_X2 & .682 & .151 & .560 & 4.503 & .000 \\
\cline { 2 - 7 } & Total_X3 & -.084 & .043 & -.193 & -1.961 & .053 \\
\hline \multicolumn{7}{|c|}{ a. Dependent Variable: Total_Z } \\
\hline
\end{tabular}

Source: Processed data, 2021

Table 4.3 Result of $\mathrm{R}^{2}$ Direct Effect of Equation 1 on $\mathrm{Z}$

\begin{tabular}{|c|c|c|c|c|}
\hline \multicolumn{5}{|c|}{ Model Summary } \\
\hline Model & $\mathrm{R}$ & R Square & Adjusted R Square & Std. Error of the Estimate \\
\hline 1 & $.745 \mathrm{a}$ & .555 & .535 & 1.843 \\
\hline \multicolumn{5}{|c}{ a. Predictors: (Constant), Total_Y, Total_X3, Total_X2, Total_X1 } \\
\hline
\end{tabular}

Source: Processed data, 2021

Table 4.4 Result of Direct Coefficients Equation 1 against Z

\begin{tabular}{|c|c|c|c|c|c|c|}
\hline \multicolumn{2}{|c|}{} & \multicolumn{2}{c|}{$\begin{array}{c}\text { Unstandardized } \\
\text { Coefficients }\end{array}$} & $\begin{array}{c}\text { Standardized } \\
\text { Coefficients }\end{array}$ & \multirow{2}{*}{ Sig. } & \\
\cline { 3 - 7 } \multicolumn{2}{|c|}{} & Bodel & Std. Error & Beta & & \\
\hline \multirow{2}{*}{1} & (Constant) & 13.351 & 3.301 & & 4.045 & .000 \\
\cline { 2 - 7 } & Total_X1 & .109 & .163 & .083 & .669 & .505 \\
\cline { 2 - 7 } & Total_X2 & .682 & .151 & .560 & 4.503 & .000 \\
\cline { 2 - 6 } & Total_X3 & -.084 & .043 & -.193 & -1.961 & .053 \\
\hline \multicolumn{7}{|c|}{ a. Dependent Variable: Total_Z } \\
\hline
\end{tabular}

Source: Processed data, 2021

\subsection{Effect of halal certification on purchasing decisions}

Based on the test results in table 4.7, where the results of the t-test obtained show a coefficient of 0.178 , the value of $t$-count $=0.818$ with a significance value of $0.415>0.05$. Thus, the first assumption (H1) in this research, namely that halal certification has a positive and significant effect on purchasing decisions, is rejected.

Halal certification refers to the provision of a halal label on a product to be traded. According to the results of this study, even though the product has included a halal label, it is not yet able to improve purchasing decisions for Sa'i Salatiga fried chicken consumers. This can happen with the assumption that consumers have not consistently chosen halallabelled products. In other words, consumers of Sa'i Salatiga Geprek Chicken can experience a decrease and increase in a certain period. 


\section{$A I C \overline{I E B}$ Annual International Conference \\ on Islamic Economics and Business, 2021}

This research is in line with the research results conducted by Akhyar \& Pramesti (2015), which states that certification has a negative and insignificant effect on purchasing decisions. On the one hand, this research rejects other findings made by (Surya 2020)) dan (Ashari, 2019) which explains that certification has a positive and significant effect on purchasing decisions.

\subsection{The effect of halal awareness on purchasing decisions}

Based on the test results in table 4.7, where the results of the t-test obtained show a coefficient of -0.354 , the value of $t$ count $=-1.581$ with a significance value of $0.117>0.05$. Thus, the second assumption $(\mathrm{H} 2)$ in this research is that halal awareness positively affects purchasing decisions.

This means that consumers are not fully aware of halal products. Because basically, consumers who understand halal products will ultimately prioritize halal food for their consumption.

This study is in line with the research results conducted by Munir et al. (2019), which states that awareness has a positive and insignificant effect on purchasing decisions. On the one hand, this research rejects the results of other findings by Munir et al. (2019), which explains that halal awareness has a positive and significant effect on purchasing decisions.

\subsection{The effect of religiosity on purchasing decisions}

Based on the test results in table 4.7, where the results of the t-test obtained show a coefficient of 0.119 , the value of $t$-count $=2.043$ with a significance value of $0.044<0.05$. Thus, the third assumption $(\mathrm{H} 3)$ in this research is that religiosity has a positive and significant effect on purchasing decisions.

Consumers who have a high level of religiosity will usually buy food that is clearly halal and always avoid activities that involve them consuming what haram is.

Consumers can judge the halalness of a product based on the level of religiosity. This is evidenced by Amin's (2019) and Vristiyana (2019), which states that religiosity affects purchasing decisions. Based on the previous findings, the following hypothesis can be formulated.

\subsection{The effect of halal certification on buying interest}

Based on the test results in table 4.8, where the results of the t-test obtained show a coefficient of 0.109 , the $\mathrm{t}$-value $=0.669$ with a significance value of $0.505>0.05$. Thus, this research rejected the fourth assumption (H4), namely that halal certification has a positive and significant effect on buying interest.

Products that have been guaranteed to be halal by being proven by halal certification, which has been proven to be safe and halal, will thus affect consumer buying interest. Halal certification is a security guarantee for a Muslim consumer to choose good food for him and follow religious rules.

This research is in line with the research results conducted by Wiliyanto (2020), which states that certification has a negative and insignificant effect on asking to buy. On the one hand, this research rejects the results of other findings conducted by Malik et al. (2019), which explains that certification has a positive and significant effect on purchase intention. 


\section{$A \mathrm{C} \overline{I E B}$ Annual International Conference \\ on Islamic Economics and Business, 2021}

\subsection{The effect of halal awareness on buying interest}

Based on the test results in table 4.8, where the results of the t-test obtained show a coefficient of 0.682 , the value of $t$ count $=4.503$ with a significance value of $0.000<0.05$. Thus, the fifth hypothesis (H5) in this research is that halal certification positively affects the accepted purchase decision.

Consumers who are aware of or understand the concept of halal, then the products they consume must have guaranteed smoothness. Thus consumer buying interest will be based on the concept of halal and increase interest in halal products. This is evidenced by research conducted by Izzudin (2018), stating that halal awareness has a positive and significant effect on buying interest in food products. The results of this study support the results of research conducted by Wiliyanto (2020), concluding that halal awareness affects consumer buying interest.

\subsection{The influence of religiosity on buying interest}

Based on the test results in table 4.8, where the results of the t-test obtained show a coefficient of -0.084 , the value of $t$ count $=-1.961$ with a significance value of $0.053>0.05$. Thus, this research rejected the sixth assumption (H6), namely that halal certification has a positive and significant effect on purchasing decisions.

Religiosity will have an impact on someone's actions to interest in buying something. Someone with a high level of religiosity allows them to be more careful in emphasizing the interest in the choice that he will determine. This study is in line with the results of a study conducted by Fauzia et al. (2019), which stated that religiosity had a negative and insignificant effect on asking to buy. On the one hand, this research rejects the results of other findings conducted by Rakhmawati (2018) and Mahardika (2019), which explains that religiosity has a positive and significant effect.

\subsection{Pengaruh minat beli terhadap keputusan pembelian}

Based on the test results in table 4.7, where the results of the t-test obtained show a coefficient of 0.980 , the $t$-count $=7.064$ with a significance value of $0.000<0.05$. Thus, the seventh assumption (H7) in this research is that buying interest has a positive and significant effect on purchasing decisions.

Buying interest arises because of a feeling of interest and wanting to have a common good or service. Following research conducted by Febiana (2014) and Agustin (2015) stated that buying interest has a positive and significant effect on purchasing decisions.

\subsection{The effect of halal certification on purchasing decisions with purchase intention as an intervening variable}

Based on the test results on path analysis, where the direct effect of halal certification on purchasing decisions is P5 $=0.094$, the indirect effect of halal certification through buying interest on purchasing decisions is 0.055942 , then the total effect of halal certification on purchasing decisions through buying interest is 0,149942

Based on the results of the calculations on the Sobel test, it is known that $t$ count $4.9563054723>\mathrm{t}$ table $=1.98580$ with a significant level of 0.05 . The conclusion is that buying interest can mediate the relationship between halal certification and purchasing decisions. Therefore, the eighth assumption (H8) in this research is that halal certification significantly affects purchasing decisions mediated by accepted purchase intentions. 


\section{$A I C \overline{I E B}$ Annual International Conference \\ on Islamic Economics and Business, 2021}

It was making halal certification one factor that determines purchasing decisions where this decision will increase buyer interest. The inclusion of writing or a statement of halal on the product packaging indicates that the product in question has the status of a halal product. So the results of this study are in line with Kamilah \& Wahyuati (2017) which states that the effect of halal certification on purchasing decisions is that buying interest is able to mediate the relationship between halal certification and purchasing decisions.

\subsection{The effect of halal awareness on purchasing decisions with purchase intention as an intervening variable}

Based on the test results on path analysis, where the direct influence of halal awareness on purchasing decisions is P6 $=0.199$, the indirect effect of halal awareness through buying interest on purchasing decisions is 0.3774 , then the total effect of halal awareness on purchasing decisions through buying interest is $-0,17844$.

Based on the results of the calculations on the Sobel test, it is known that $t$ count $3.1979620346>\mathrm{t}$ table $=1.98580$ with a significant level of 0.05 . The conclusion is that buying interest can mediate the relationship between halal awareness and purchasing decisions. Therefore, the ninth assumption (H9) in this research is that halal awareness significantly affects purchasing decisions mediated by accepted purchase intentions.

Someone who knows and understands the halal concept is more interested in buying because they prioritize consuming halal food. This research is in line with research conducted by Rizaldi (2020), which examines the effect of halal awareness on purchasing decisions mediated by buying interest, showing that halal awareness has a positive and significant effect on purchasing decisions and buying interest can mediate the positive influence of halal certification on purchasing decisions. The results of this study are in line with research conducted by Rizaldi (2020), which explains that buying interest can mediate the relationship between halal awareness and purchasing decisions. The influence of religiosity on purchasing decisions with buying interest as an intervening variable

Based on the test results on path analysis, where the direct influence of halal certification on purchasing decisions is $\mathrm{P} 7=-0.189$, the indirect effect of religiosity through buying interest on purchasing decisions is -0.130082 , then the real influence of religiosity on purchasing decisions through buying interest is $-0,313082$.

\subsection{The influence of religiosity on purchasing decisions with buying interest as an intervening variable}

Based on the results of the calculations on the Sobel test, it is known that $\mathrm{t}$ count $3.2873250856<\mathrm{t}$ table $=1.98580$ with a significant level of 0.05 , so the conclusion is that buying interest cannot be an intermediary for the relationship between religiosity and purchasing decisions. Therefore, the tenth assumption (H10) in this research, namely that religiosity significantly affects purchasing decisions mediated by buying interest, is rejected.

Consumers will choose a product that does not conflict with their religion. The consumption activities of an individual are very closely related to the quality of appreciation of the religious values they believe in because, for them, religion is the main source. Judging from the behaviour of religious consumers, it shows that consumers care about religious issues. The above statement is supported by previous research that religiosity significantly influences purchasing decisions through buying interest.

The results of this study are in line with research conducted by Akhyar \& Pramesti (2015), which explains that buying interest cannot mediate the relationship between religiosity and purchasing decisions. However, this study also rejects other findings carried out by Abdillah (2020) that religiosity significantly influences purchasing decisions through buying interest. 


\section{$A \mathrm{C} \overline{I E B}$ Annual International Conference \\ on Islamic Economics and Business, 2021}

\section{Conclusion}

The results show that of the ten proposed hypotheses, five are accepted, and five are rejected. This study proves that halal certification, halal awareness and religiosity are proven to influence purchasing decisions through buying interest.

Through SPSS calculations, the seven hypotheses analyzed using the t statistical test showed a significant relationship between the variables because they had a lower significance level than the specified alpha $(0.000<0.05)$. A path analysis test was conducted to determine the effect of intervening variables contained in the research model. The results prove that halal certification, awareness, and religiosity affect purchasing decisions through buying interest, so hypotheses 8,9 and 10 are accepted.

\section{References}

Abdillah, L. J. (2020). Pengaruh Desain Produk, Citra Merek, Dan Religiusitas Terhadap Keputusan Pembelian Dengan Minat Beli Sebagai Variabel Intervening Pada Produk Maternal Disaster Skripsi.

Agustin, R. (2015). Pengaruh Green Marketing Terhadap Minat Beli Serta Dampaknya Pada Keputusan Pembelian (Survei Pada Konsumen Non-Member Tupperware Di Kota Malang). Jurnal Administrasi Bisnis S1 Universitas Brawijaya, 22(2), 85919.

Ahmad, N. A., Abaidah, T. N. T., \& Yahya, M. H. A. (2013). a Study on Halal Food Awareness Among Muslim Customers in Klang. 4Th International Conference on Business and Economic Research Proceeding, March, 1073-1087.

Ajzen, I. (1991). The Theory of Planned Behavior Organizational Behavior and Human Decision Processes. Organizational Behavior and Human Decision Processes, 50(2), 179-211.

Ajzen, I. (2002). Perceived Behavioral Control, Self-Efficacy, Locus of Control, and The Theory of Planned Behavior. Organization Behavior and Human Decision Processes 50.

Akhyar, K. F., \& Pramesti, D. A. (2015). Pengaruh religiusitas dan sertifikasi halal terhadap keputusan pembelian (studi empiris pada japanese food restaurant di Magelang). Jurnal Analisis Bisnis Ekonomi, 13(2), 617.

Amin, M. A. (2019). " pengaruh islamic branding dan religiusitas terhadap keputusan pembelian produk pada swalayan basmalah cabang rembang pasuruan jawa timur."

Anggadwita, G., Alamanda, D. T., \& Ramadani, V. (2020). Halal Label vs Product Quality in Halal Cosmetic Purchasing Decisions. Ikonomika, 4(2), 227-242. https://doi.org/10.24042/febi.v4i2.5897

Armstrong, G., Adam, S., Denize, S., \& Kotler, P. (2014). Principles of marketing. Pearson Australia.

Ashari, M. (2019). Pengaruh Pengetahuan Produk Dan Sertifikasi Halal Terhadap Keputusan Pembelian Produk Farmasi Di Desa Mojorejo Kecamatan Kebonsari Kabupaten Madiun. 1-93.

El-Menouar, Y. (2014). The Five Dimensions of Muslim Religiosity . Results of an Empirical Study. Method, Data, Analyses, 8(1), 53-78. https://doi.org/10.12758/mda.2014.003

Fauzia, diah retno sufi, Pangestu, E., \& Bafadhal, A. S. (2019). Pengaruh religiusitas, sertifikasi halal, bahan produk terhadap minat beli dan keputusan pembelian. Jurnal Administrasi Bisnis (JAB), 66(1), 37-46.

Febiana, D. (2014). Pengaruh Word of Mouth terhadap Minat Beli Serta Dampaknya pada 


\section{$A I C \overline{I E B}$ Annual International Conference \\ on Islamic Economics and Business, 2021}

Keputusan Pembelian (Survei pada Pengunjung yang Melakukan Pembelian pada Bikerâs Resto dan Cafe di Kota Malang). Jurnal Administrasi Bisnis S1 Universitas Brawijaya, 16(1), 84966.

Ghozali, I. (2013). Apikasi Analisis Multivariate Dengan Program IBM SPSS 21 Update PLS Regresi (Cetakan ke). Badan Penerbit Universitas Diponegoro.

Harfania, F. (2018). Pengaruh Promosi Penjualan , Experiential Marketing, Kualitas Produk Dan Kualitas Pelayanan Terhadap Minat Beli Ulang ( Studi Kasus Pada Restoran Ayam Geprek Sa ’ I Yogyakarta ). Jurnal Fakultas Ekonomi, 3, 581-591.

Izzudin, A. (2018). Pengaruh Label Halal, Kesadaran Halal Dan Bahan Makanan Terhadap Minat Beli Makanan Kuliner. Penelitian Ipteks, 3(2), 100-114. http://jurnal.unmuhjember.ac.id/index.php/PENELITIAN_IPTEKS/article/view/1886 $/ 1547$

Kamilah, G., \& Wahyuati, A. (2017). Pengaruh Labelisasi Halal Dan Brand Image Terhadap Keputusan Pembelian Melalui Minat Beli. Jurnal Ilmu Dan Riset Manajemen, 6(2), 118.

Kotler, P., \& Lee, N. (2008). Social marketing: Influencing behaviors for good.

Kusumawati, D., \& Saifudin. (2020). Pengaruh Persepsi Harga Dan Kepercayaan Terhadap Minat Beli Secara Online Saat Pandemi Covid-19 Pada Masyarakat Millenia Di Jawa Tengah. 6(01), 1-13.

LPPOM MUI. (2020). Data Statistik Produk Halal LPPOM MUI Indonesia 2012-2019. Halalmui.Org. http://www.halalmui.org/mui14/main/page/data-statistik-produk-halallppom-mui-indonesia-2012-2019

Mahardika, T. P. (2019). Pengaruh Pengetahuan dan Religiusitas Terhadap Minat Beli dengan Sikap Konsumen sebagai Variabel Mediasi (Studi pada Pengguna Kosmetik Wardah di Yogyakarta). Jurnal Ilmu Manajemen, 16(2), 2019. https://barnard.edu/sites/default/files/inline/student_user_guide_for_spss.pdf\%0Ahttp ://www.ibm.com/support\%0Ahttp://www.spss.com/sites/dmbook/legacy/ProgDataMgmt_SPSS17.pdf\%0Ahttps://www.nepsdata.de/Portals/0/Working Papers/WP_XLV.pdf\%0Ahttp://www2.psy

Malik, R. F., Hermawan, A., \& Asnawi, Y. H. (2019). the Effect of Halal Awareness, Halal Certification and Halal Marketing Toward Halal Purchase Intention of Fast Food Among Muslim Millenials Generation. Russian Journal of Agricultural and SocioEconomic Sciences, 90(6), 76-83. https://doi.org/10.18551/rjoas.2019-06.11

Munir, M., Hidayat, K., Fakhry, M., \& Mu'tamar, M. F. F. (2019). Pengaruh Pengetahuan Halal, Kesadaran Halal (Halal Awareness) Dan Label Halal Terhadap Keputusan Pembelian Produk Jamu Madura. Agroindustrial Technology Journal, 3(2), 95. https://doi.org/10.21111/atj.v3i2.3858

Nofianti, K. A., \& Rofiqoh, S. N. I. (2019). Kesadaran Dan Logo Halal: Apakah Menentukan Minat Beli? (Studi Pada Praktisi Bisnis Umkm Di Gresik). Journal of Halal Product and Research, 2(2). https://doi.org/10.20473/jhpr.vol.2-issue.2.51-59

Rakhmawati, A. (2018). Pengaruh Label Halal Dan Religiusitas Terhadap Minat Beli Dan Keputusan Pembelian (Studi Pada Wardah Beauty House Surabaya).

Riaz, M. N., \& Chaudry, M. M. (2003). Halal food production. CRC press.

Rizaldi, Mu. W. (2020). Analisis Halal Awareness Terhadap Keputusan Pembelian Konsumen Shopee Di Indonesia Dengan Minat Beli Sebagai Variabel Intervening. Universitas Pendidikan Indonesia.

Saifudin, \& Puspita, R. E. (2020). Predicting the Intention of Millennial Moslems to Visit Halal Tourism. 8, 129-142.

Stark, R., \& Glock, C. Y. (1968). American piety: The nature of religious commitment (Vol. 1) (M. M. (2003). H. food production. C. press. Riaz, M. N., \& Chaudry (ed.)). University of California Press. 


\section{$A I \overline{I F B}$ Annual International Conference \\ on Islamic Economics and Business, 2021}

Sugiyono. (2015). Metode Penelitian Kuantitatif, Kualitataf dan R\&D. Alfabeta.

Surya, R. (2020). Pengaruh sertifikasi halal terhadap keputusan pembelian konsumen (studi kasus pada usaha.

Syahputra, A., \& Hamoraon, H. (2014). Pengaruh Labelisasi Halal Terhadap Keputusan Masyarakat Kecamatan Perbaungan Dalam Pembelian Produk Makanan Dalam Kemasan. Jurnal Ekonomi Dan Keuangan, 2(8), 14806.

Vristiyana, V. M. (2019). Pengaruh Religiusitas Dan Pengetahuan Produk Halal Terhadap Penilaian Produk Halal Dan Minat Pembelian Produk Halal (Studi Kasus Pada Industri Makanan). Jurnal Ekonomi Dan Bisnis, 20(1), 85. https://doi.org/10.30659/ekobis.20.1.85-100

Wiliyanto. (2020). Pengaruh labelisasi halal, variasi produk, dan kesadaran halal terhadap minat beli.

Yunus, N. S. N. M., Rashid, W. E. W., Ariffin, N. M., \& Rashid, N. M. (2014). Muslim's Purchase Intention towards Non-Muslim's Halal Packaged Food Manufacturer. Procedia - Social and Behavioral Sciences, 130, 145-154. https://doi.org/10.1016/j.sbspro.2014.04.018 